UDK 78 Krek U.

Niall O'Loughlin

Univerza $\mathrm{v}$ Loughbourghu

Loughborough University

\title{
Expressive Emotion and Symphonic Economy: A Note on Recent Works by Uroš Krek
}

\author{
Emocionalna izraznost in simfonična \\ ekonomičnost: \\ Beležka k novim skladbam Uroša Kreka
}

Ključne besede: Uroš Krek, Slovenija, komorna glasba, godala, melodični motivi

PovZetek

Uroš Krek povezuje v svoji glasbi simfonično ekonomičnost $z$ emocionalno izraznostjo. To je videti že tudi v njegovih zgodnejših neoklasicističnih delih in skladbah, napisanih pod vplivom ljudske glasbe. Mnogo od teh del je bilo namenjenih godalom, ki jim je Krek še posebej naklonjen. V Krekovi glasbi 70 . let je opaziti široko uporabo izjemno razvitega motivičnega dela, v katerem se kaže skladateljev posebej spreten pristop. Svoje motive spreminja ritmično, $z$ inverzijo, $s$ preurejevanjem in spreminjanjem tonov. Te značilnosti so zelo jasne tudi v novejših delih, tako v Godalnem sekstetu iz 1990, v katerem edinstveno in prepričljivo povezuje variacijsko tehniko ter motivično transformacijo $\mathrm{z}$ intenzivno emocionalno izraznostjo.
Keywords: Uroš Krek, Slovenia, chamber music, string instruments, melodic motives

\section{SUMMARY}

The music of Uroš Krek combines symphonic economy with expressive emotion. Even in the earlier neo-classical and folk music influenced works, this character was evident. Many of these works are written for string instruments for which Krek has a particular interest and affinity. The music of the 1970s contains an extensive use of a highly developed motivic activity which shows his flexible approach. His motives change by rhythm, inversion, reordering, and changing notes. These features are also very evident in more recent works, notably the Streichsextett of 1990 which combines variation technique and motivic transformation in a unique and satisfying way with an intense emotional expression.

For over half a century the music of Uroš Krek has impressed the musical world with its skill, imagination and variety. It has a distinctive voice, but its style includes many clear strands: one can note certain influences, but they are almost always so fully absorbed into the textures and idiom that it would be inaccurate to use the word 'eclectic'. One of Krek's earliest works, the Simfonietta of 1951, is notable for its engaging neoclassical idiom and its tight symphonic economy: it is these two features, representing heart and mind respectively, which appear so strongly in most of his music.

As a string player himself Krek naturally exploited the possibilities of string sound in the following years. Two such works from this time are outstanding: Mouvements concertants of 1955 and the Sonatina for strings of 1956. The former is forward looking and 
full of conflict. Gone are the easy-going and entertaining melodies of the Simfonietta; in their place is a collection of emotionally charged motives that present a conflict that finally resolves itself in an amazingly structured and finally peaceful passacaglia on an original theme. The Sonatina is not so full of conflict, but again it uses short and fertile motives with an economy that is hardly suggested by the exuberant tone of the work.

From 1958 to 1967 the composer's position as a researcher at the Ethnographic Institute in Ljubljana gave him access to and familiarity with large numbers of folk melodies. This affected his original music in much the same way as a similar experience affected Béla Bartók. Krek occasionally arranged folk music for modern performers, as in Pet ljudskih pesmi of 1963, in which songs from Rezija, Medjimurje and Prekmurje are given with modern piano accompaniments. Normally, however, he took elements from folk music practice and incorporated these into his already established style. One can sense that this happened very soon as in his Rapsodični ples ('Rhapsodic Dance') for orchestra of 1959. Here the motives on which the work is built have the distinct inflections of folk music, short scalic runs and the use of the interval of the augmented second, for example, but they are used in a 'symphonic' manner which makes it clear that Krek is simply imbuing his music with the spirit of the music of his country.

Four works for solo performer and orchestra, dating from the 1960s, show Krek absorbing folk influence into his music in a natural and subtle way. In the Concerto for horn and strings of 1960 he contrasted a free horn melody with a predominantly rhythmic section that uses $8 / 8$ time divided into $3+2+3$, a common folk rhythm from Slovenia and the Medjimurje region of Croatia. Similarly in the brilliantly delicate Concertino for piccolo and orchestra of 1967, there are passages of folk-derived rhythms, e.g. in the coda of the second movement. The more introspective and emotionally charged concerto, Inventiones ferales for violin and strings of 1962, used the Istrian mode for some of its melodic material, in a disguised manner, while there are melodic lines with simple, folklike stepwise movement in the visionary song-cycle with string orchestra, Staroegiptov ske strofe ('Old Egyptian Verses'). Krek's use of folk-derived elements took their place very naturally in his style.

Even in these works there are the beginnings of new techniques. The Concertino for piccolo has increasing use of passages of free rhythm in unbarred sections and Staroegiptovske strofe use recitative techniques. These now make a modest appearance in works from the 1970s such as the Sinfonia per archi of 1973. Much more important than this is the extension of the use of melodic motives and cells which dominate Krek's musical thinking in the years 1970-80. A flexible approach to rhythmic variety and variations in the intervals used in these motives is a dominating feature of the Solo-Sonata for two violins of 1972. Yet this work is not an abstruse intellectual exercise, but a vigorous creation of Bartókian splendour. Krek's manipulation of melodic cells in the homophonic, heterophonic and contrapuntal sections of his Sinfonia per archi is very impressive, but the work's intensity is never compromised by this melodic economy. The same can be said of two other string works of the time, the Duo for violin and viola and the Trio for string trio, and the piano piece, Sur une mélodie, of 1977. It is, however, the second movement of the Sonata for clarinet and piano (completed in 1977) that is a tour-deforce of motivic working, a staggering display of how these fragments can be repeated, juggled, transformed and juxtaposed. Again the intellectual side of the piece is balanced by a warm and moving intensity in the first movement and in the second movement an exultant virtuosity that always arises from the needs of the music.

Krek's more recent works have built on the methods established in his earlier music. These techniques, applied imaginatively and almost unobtrusively as part of the compo- 
ser's style, can be found in vocal and instrumental works for many different combinations. The small-scale choral works, for example, use a well-managed combination of homophonic and contrapuntal techniques. Three Autumn Songs from 1991 for mixed chorus combine straightforward but subtly varied imitation between the different voices, sometimes by inversion, with chordal passages of an unambiguous luminosity that one finds at all stages in the composer's career. The English words of John Gracen Brown are treated with great sensitivity, for example, in the closing bars of the third song where autumn is turning to winter. The texture and harmonic progression are simple, but the false relations create a very colourful sound. We can find many of the same features in the setting of the 42nd psalm, Salmo XLII also of 1991. Here the opening Latin words are presented imitatively but unpredictably in the different parts. Again the word setting is very clearly intended to be heard, with numerous examples of words sensitively presented. The Latin words of the Roman poet Horace (Quintus Horatius Flaccus) are set vividly by Krek in the four-part chorus, Vester, Camenae of 1994. While the composer keeps his music within a broad tonality, his use of a wide range of dissonance points the meaning of the words very clearly. The setting of Jutranja pesem ('Morning Song') by Adam Bohorič (1520-98) dates from 1996. The accompaniment of brass quintet and bells is a typically unusual touch by Krek. It is very interesting how, even in such a short piece, he builds up a range of motives that infiltrate the texture without ever dominating the choral parts. In some respects it is a little like the Baroque chorale prelude in its treatment, with the choir's music presented homophonically and the instrumental parts acting mostly as a counterpoint until the final bars in which the words, 'bratce, sestrice in vso družbo. Amen', are sung in a blaze of glory by the choir, accompanied by brass with the bells ringing above the other sounds.

A single voice and solo brass instrument are both featured in Krek's thanksgiving cantata for soprano, trumpet and organ called Cantus gratias agentis - Zahvalni spev of 1994, set to Krek's own Latin words. Although only a short work, it falls into a number of short sections. It appears something like a baroque passacaglia but that is only a superficial impression; rather Krek treats the opening section to a series of free variations. In the same way as in earlier works the various melodic cells or motives are expanded, contracted or transformed in the composer's flexible manner. The soprano part and the trumpet's mostly ornamental or connecting phrases derive their melodic lines from the opening organ part. The form of the work is well tailored to the words. Three times Krek sets to the same melodic phrase the refrain, 'Laudibus te effero et tibi gratias ago' (I cover you with praises and give you thanks). It is placed after the opening verse, a second time in the middle of the work, and a third time at the end, each time set. Between each statement the music moves through a harmonic and melodic fantasy before returning each time to the spiritual core of the work. It is the contrast of intense emotion with his economy of means which gives the work its power.

Krek's recent work has been marked by a number of works for solo instrument and piano. What is immediately apparent in these works is the composer's handling of form which shows little debt to any models, but is always controlled by a skilful handling of motives and harmonic material. Typical of this is his single-movement Appassionato for flute and piano of 1989, whose subtitle gives a clue to the composer's method: parafrasi per flauto e pianoforte. Like Cantus gratias agentis it is written as a single movement in a number of sections of varying tempos which are almost seamlessly linked by the similarity of motives. Its fantasy character is immediately apparent. At the same time Krek establishes his musical motives in a subtle fashion: the piano's accompanying figures achieve a strong unity by balancing repetition and change. The development of new 
phrases out of previous ones is a technique that Krek features very strongly here and one that links the sections. Yet there is also a connection with traditional formal structures: the opening slow sections (Moderato - Poco piu largamente - Piu mosso - Andante Lento) form the first 'movement', the next two (Allegretto, pochissimo meno mosso del movimento precedente - Quasi marcia) form a march-like movement but are linked by a dominant triplet motive that featured strongly in works of the 1970s, the next two (Moderato - Poco piu largamente) form a slow introduction to the brilliant dance-like final Allegro assai which is the longest section in the work.

Even a modest single-movement work like the charming Sarabanda per Nataša of 1993 for clarinet and piano is scrupulously worked out in all its motivic transformations. One example is a triplet figure that moves by step but is constantly changing its tones and semitones. The more extended and substantial Invocazione for oboe and piano of the previous year develops its material from the opening recitative-like opening statements from the oboe in a way that the attentive listener can follow without difficulty. As in Appassionato for flute the shorter sections are naturally grouped by their sharing of melodic motives and by the skilfully composed transitions between them. The $2 / 4$ final section marked Animato concludes the work in a dance-like way that displays the same spirit that informs Krek's neo-classical music of the 1950s, while at the same time showing a neat and precise economy of melodic motives.

While Krek's writing for wind instruments is sonically effective and gratefully written, even if sometimes difficult to play, his music for string instruments is exceptional. Two recent works for violin and piano are good examples: Vigoroso of 1991 and Seconda sonata (Erinnerungen) of 1994. The former is a single-movement multi-tempo piece that lasts just under ten minutes. The way that Krek builds up his form is fascinating: the opening Movimentato in 12/8 time sets the character for the three parts of the opening section as well as for the closing section. Between these there is a brilliant dance-like section in 3/8 and a short Largo. The four broad sections are played without a break with thematic connections that are not immediately obvious. The whole has a fantasy character with some features which suggest folk violin playing, notably the almost Bartókian violin phrases of the opening (Ex.1). As with much of Krek's music the music has a
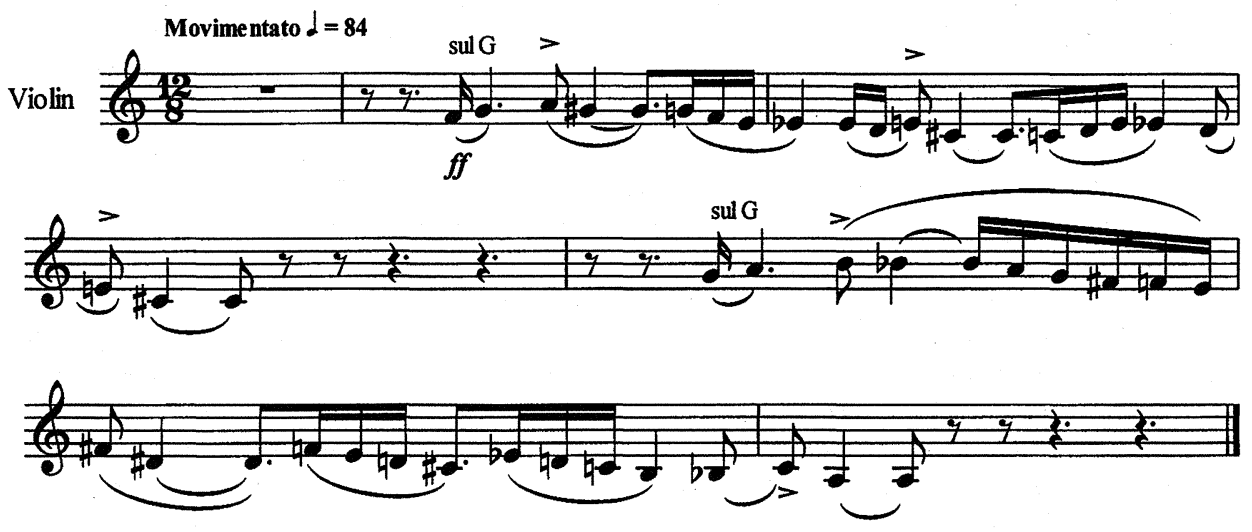

Ex.1 Uroš Krek: Vigoroso per violino e pianoforte (bars 1-7, violin part only) 
strong emotional character coupled with thematic unity. Seconda sonata (Erinnerungen) is more expansive and, unlike many recent works, cast in three separate movements. The headings of these movements, Contemplativo, Inquieto and Giusto, give some idea of their individual characters, but, as in the single movement works, there is considerable variety within each one. The first and third movements are very free ternary structures, with the first based on a recitative that is fertile with motives, and the third on a developing melodic formula whose $5 / 4(2+3)$ metrical pattern is used to great effect to build up tension. The central movement, entitled 'Inquieto', has a much more subtle construction: the plan, according to tempo, can be seen as ABACA, but with the constant interplay of motives, this sounds more like a free fantasy.

One of the motives that appears in one form or another in all three movements, has a long history in Krek's music. His works from the 1970s frequently feature a triplet of semiquavers followed by a quaver or crotchet. The notes rise twice and then fall back to a central one (or move in the opposite direction): typically this consisted of a rising third, then a sixth, falling back to the third. Ex.2 takes the clarinet part of the opening of the

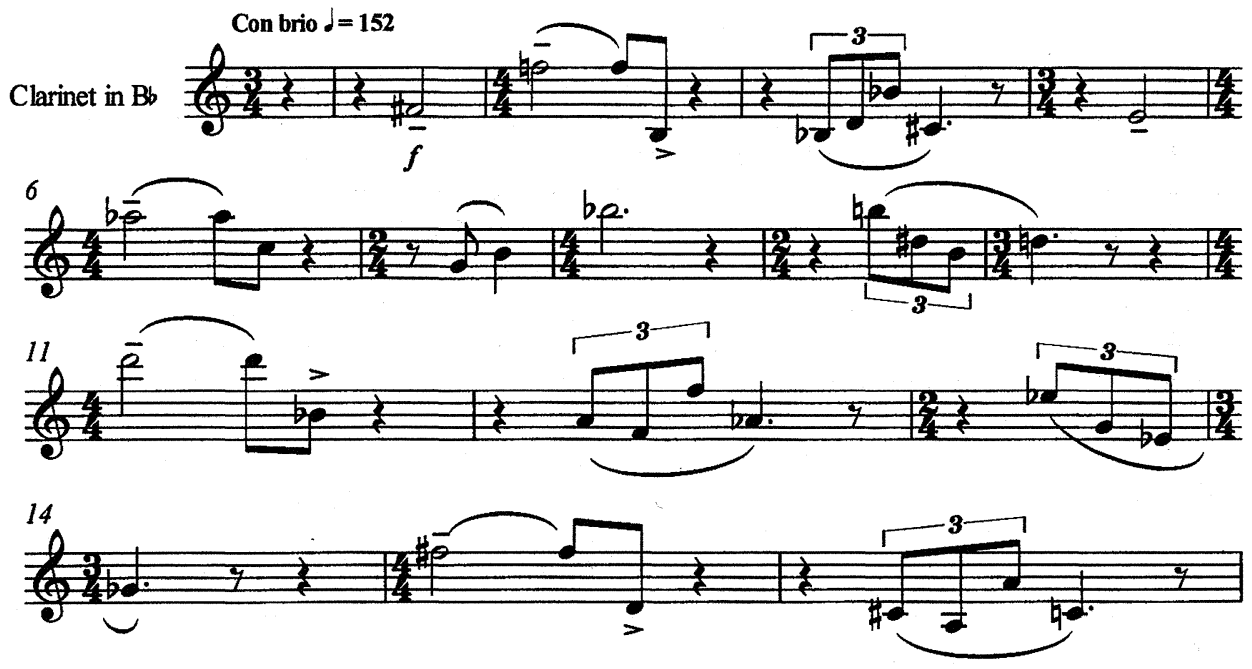

Ex. 2 Uroš Krek: Sonata for clarinet and piano (2nd movement, bars 1-16, clarinet part only)

second movement of the Sonata for clarinet and piano of 1977. Bar 4 has the motive in its rising form and bars 9-10 in its falling version. Note, however, that the note following the triplet is a semitone lower than the middle note of the triplet whichever direction it is played. In bars 12 and 16 the first and second notes of the triplet are reversed while still leaving the note following the triplet a semitone lower than the middle-pitched note of the triplet. At other places in this movement Krek alters the triplet's order and the intervals as a way of creating variety. In the Seconda sonata this triplet takes many forms, but 
it is immediately recognisable in most cases. Ex.3 shows how Krek incorporated this triplet type (but with different intervals) into the second movement of his sonata. Note how here the intervals change in bars one, five and six. This use of a particularly identifiable but constantly changing motive is a hallmark of the composer's style and a strong unifying factor.

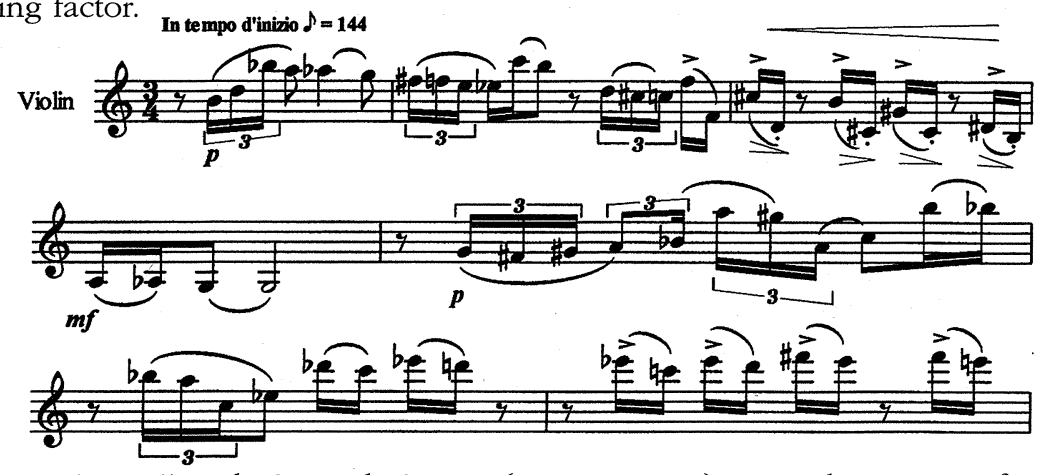

Ex. 3 Uroš Krek: Seconda Sonata (Erinnerungen) per violino e pianoforte (2nd movement 'Inquieto', bars 59-65, violin part only)

The freedom with which he treats the changing identity of his motives identity gives a clue to the understanding of the variation technique of the last work to be considered in this survey, Streichsextett über ein Thema von Frank Martin of 1990, composed for the Zurich String Sextet. Krek's choice of a theme by Frank Martin was a tribute to the nationality of the Swiss players, but it was also because of the affinity that Krek's music has with the music of Frank Martin. The work's emotional tone is very strong with a powerful intensity immediately obvious in the harmonies found in the theme taken from the opening of the second movement of Frank Martin's Cello Concerto. This atmosphere is maintained throughout despite the many tempo changes and the constantly changing textures which are enabled by the six string parts.

Although written as a continuous piece of nearly twenty minutes' duration, it is composed in nine distinct sections: Theme - Interlude 1 - Variation 1 - Interlude 2 -Variation 2 Variation 3 - Interlude 3-Variation 4 - Postlude. Because the theme and the first interlude form a unified section, the work naturally falls into a symmetrical pattern (see Table 1).

\begin{tabular}{|l|l|l|}
\hline Theme & Adagietto & $3 / 4$ \\
\hline Interlude 1 & ['istesso tempo] & $3 / 4$ \\
\hline Variation 1 & Poco piu movimentato & $3 / 4$ also 2/4, 4/4 \\
\hline Interlude 2 & Giocoso - Sostenuto - Solenne - Tempo primo & $3 / 8$ \\
\hline Variation 2 & Grave - Poco più mosso - Tempo primo & $4 / 4,3 / 4,4 / 4$ \\
\hline Variation 3 & Ruvido & $3 / 2,2 / 2,3 / 2$ \\
\hline Interlude 3 & Calmo - Doppio movimento - Tempo primo & $3 / 4,2 / 4,3 / 4$ \\
\hline Variation 4 & Risoluto pesante & $4 / 4$ \\
\hline Postlude & Allegretto & $3 / 4$ \\
\hline
\end{tabular}

Table 1: Uroš Krek: Streichsextett über ein Thema von Frank Martin (overall plan) 
MUZIKOLOŠKI ZBORNIK - MUSICOLOGICAL ANNUAL XXXVIII

The all-important three-note motive appears immediately in all the string parts of Frank Martin's theme (Ex.4). This is taken in its original form and rescored for the string sextet.
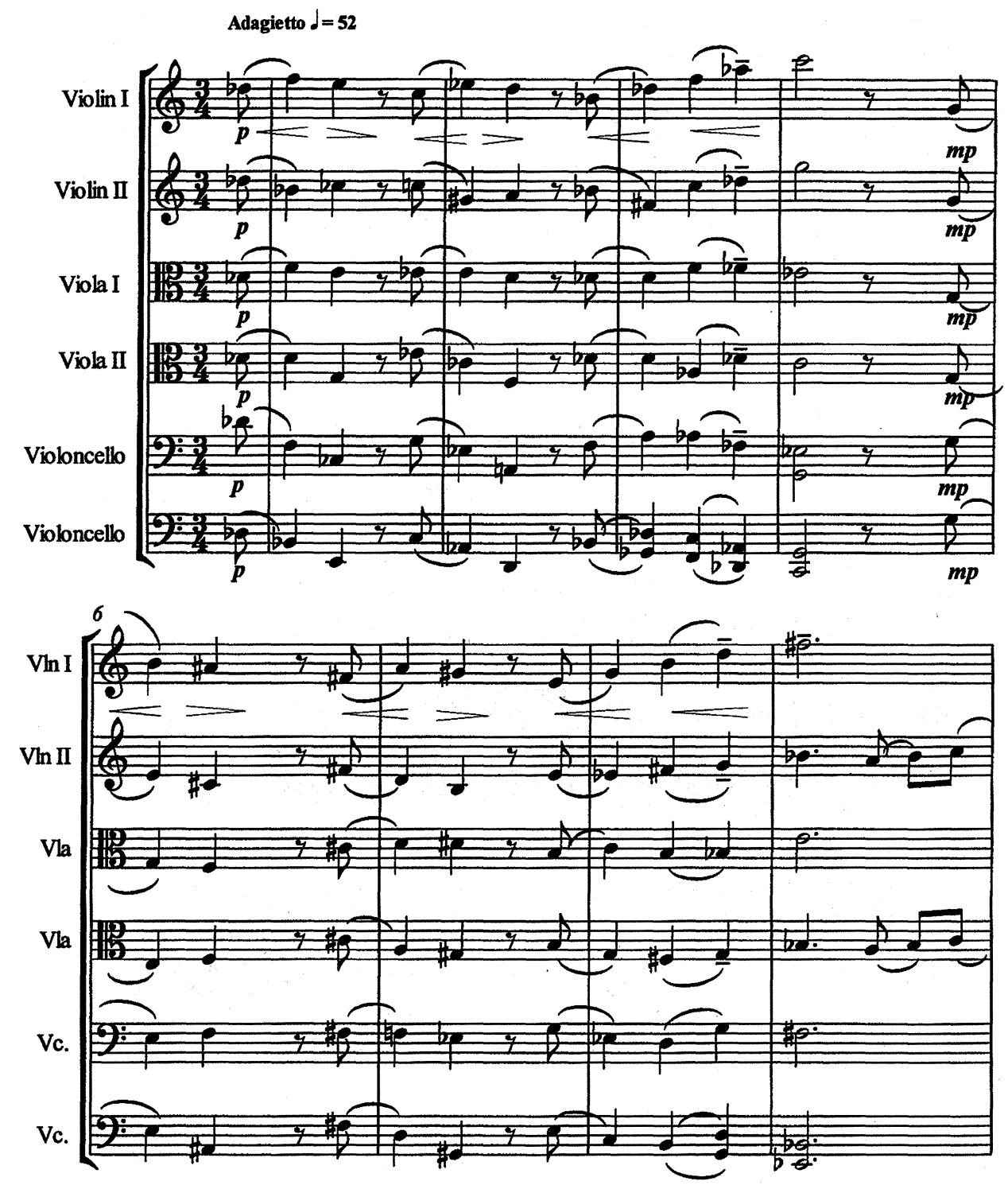

Ex. 4 Uroš Krek: Streichsextett über ein Thema von Frank Martin (Theme: Adagietto) 
Note first the rising third (both major and minor) and falling semitone in the first violin part and its inversion in the second violin part, and secondly the sequence of rising thirds. In the first interlude which treats the motives in imitation between the upper three parts and the three lower ones, Krek has spliced his music seamlessly to Frank Martin's. The variations, interludes and postlude that follow saturate the textures with these motives and their transformations. Variation 1 alters the rhythm, sometimes the order of notes, and adds counterpoints built from the motives. The transition to the second interlude is achieved by changing the motive into a very quiet ostinato which is interrupted by brief fast outbursts of the opening motive which is then lengthened, poco nostalgico, in octaves in the violins. Ex.5 gives a long passage from the last part of Interlude 2 that presents the fast ostinato, the augmented version of the opening motive, and the triplet figure, in various combinations and juxtapositions, sometimes with extra notes added to the basic three-note motive.

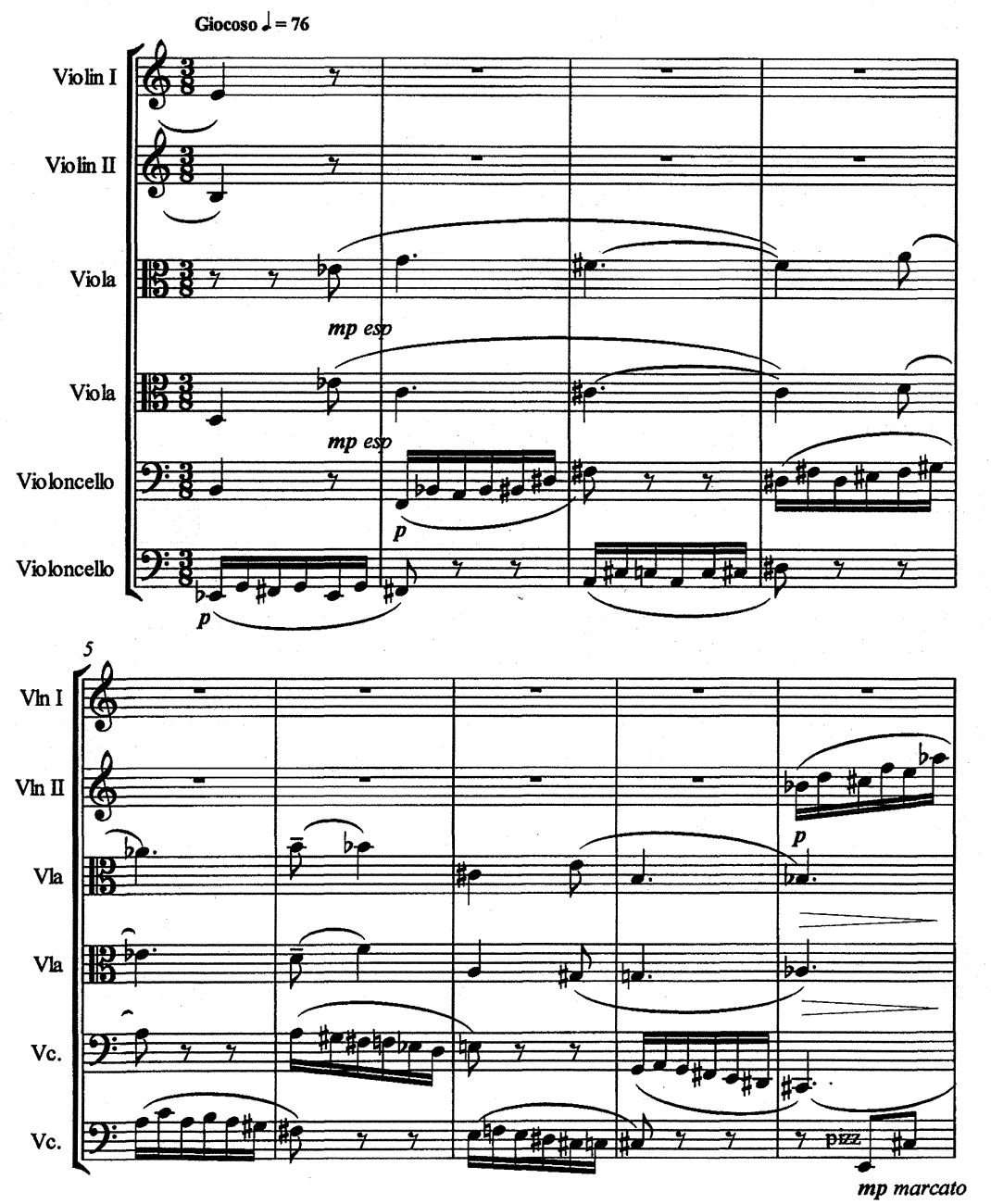

Ex.5 Uroš Krek: Streichsextett über ein Thema von Frank Martin (from Interlude 2) 
MUZIKOLOŠKI ZBORNIK • MUSICOLOGICAL ANNUAL XXXVIII
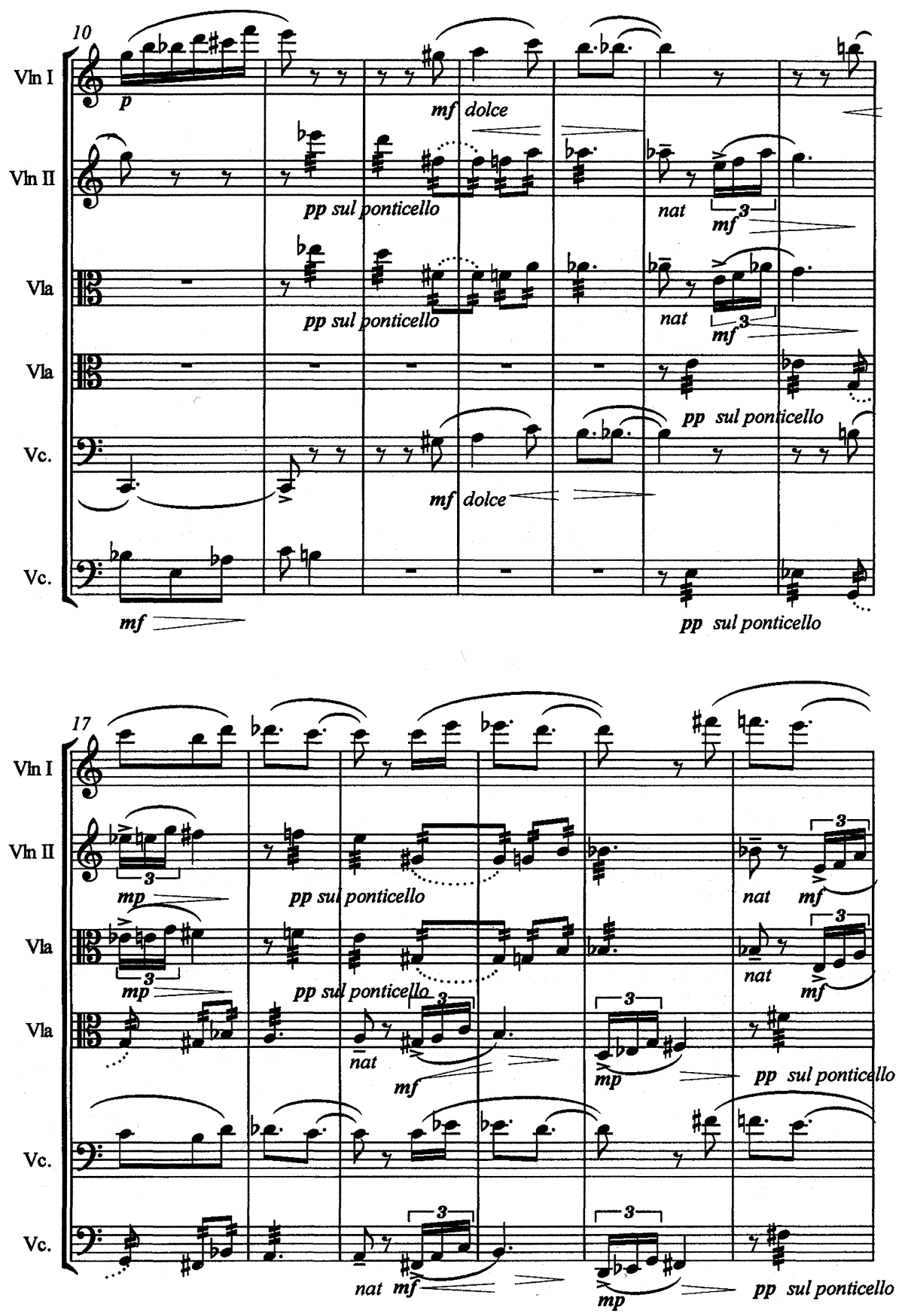

Ex.5 (continued) 
MUZIKOLOŠKI ZBORNIK • MUSICOLOGICAL ANNUAL XXXVIII
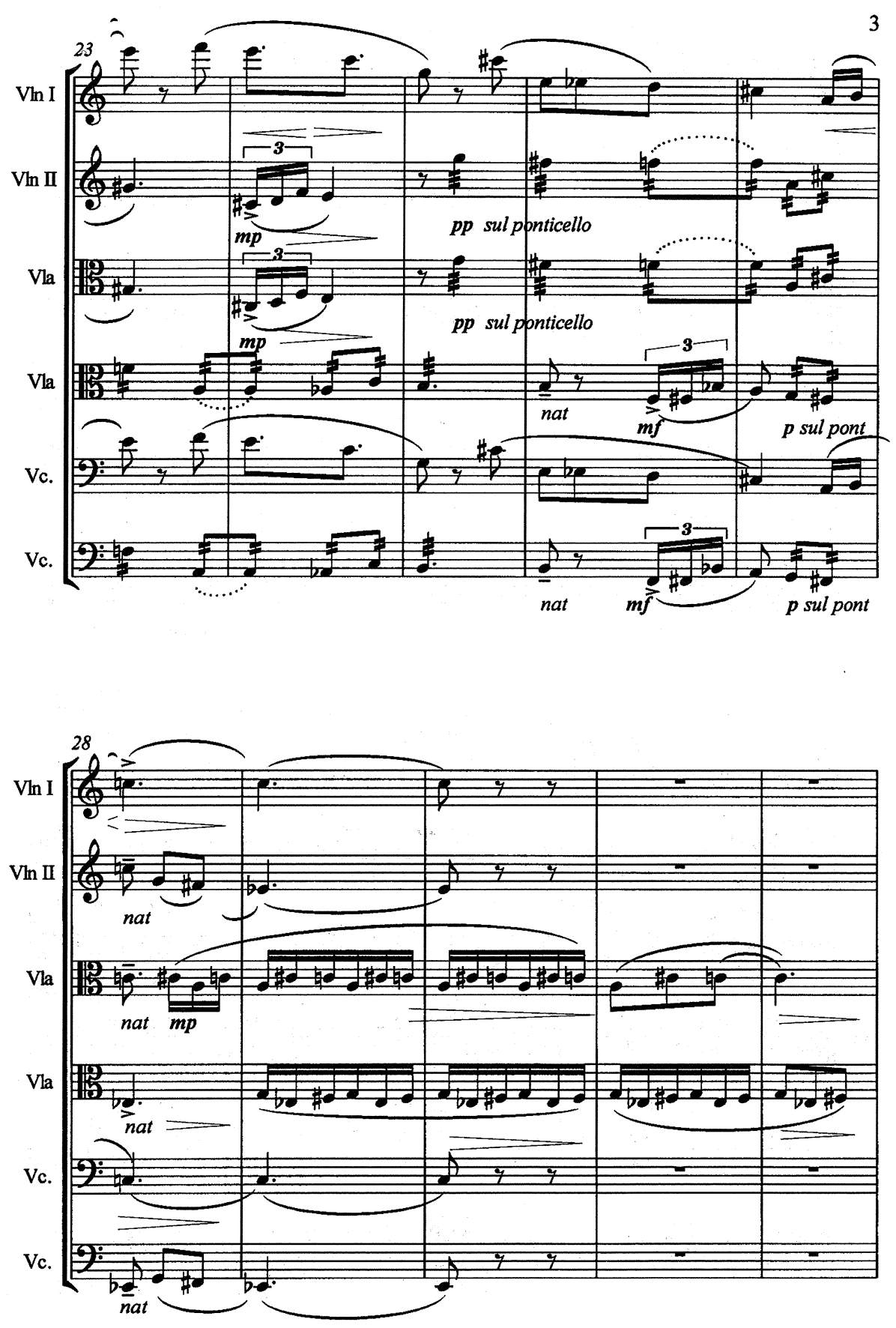

Ex.5 (continued) 
It is completely typical of the flexible variation technique that Krek used in this work. After the slow and emphatic Variation 2, the composer subjects his melodic fragments to a virtuoso treatment of strong rhythmic drive in Variation 3. The expressive relaxation of Interlude 3 recalls the intensity of the theme itself but develops the motivic activity very clearly. The central section (Doppio movimento) adds newly derived elements in counterpoint to the mainly slowly moving lines found in the outer sections. It is somewhat tedious to describe the processes that Krek uses in the Streichsextett, as they depend for their effect on an audible association of ideas that is not always straightforward to explain.

The fact that this constant flux of motives is being handled so apparently effortlessly makes the work's intense expression so easily communicated. It is in fact this combination of motivic economy and expressive sound that gives Krek's music its distinctive character and its unique power. 